Tools and Technology

\title{
Quantifying Relative Levels of Solar Radiation at Bat Roosts Using Pyranometers
}

\author{
KRISTIN J. BONDO, ${ }^{\mathbf{1 , 2}}$ University of Regina, Department of Biology, 3737 Wascana Parkway, Regina, SK S4S OA2, Canada \\ DAVID R. BROOKS, Institute for Earth Science Research and Education, 2686 Overhill Drive, Eagleville, PA 19403, USA \\ R. MARK BRIGHAM, University of Regina, Department of Biology, 3737 Wascana Parkway, Regina, SK S4S 0A2, Canada
}

\begin{abstract}
Although the amount of solar radiation received at roost sites used by bats has been speculated to be a factor driving roost-site selection and roost switching behavior, few studies have scientifically quantified and recorded it over time. We demonstrated through a field test how silicon-cell pyranometers, which are commonly connected to dataloggers and used in atmospheric studies to measure solar irradiance on a planar surface, can also be used to measure and record relative solar radiation levels at roost trees used by bats and other wildlife. Using commercially available pyranometers might not be feasible for many wildlife studies because they are expensive; we demonstrate how they can be built relatively simply and inexpensively, and calibrated with a commercial silicon-cell pyranometer. (c) 2017 The Wildlife Society.
\end{abstract}

KEY WORDS bat, cavity, Eptesicus fuscus, pyranometer, roost, Saskatchewan, solar radiation, tree.

For many animals, microclimate is an important determinate influencing the location of shelter. This is especially true for small endotherms that have a high surface area-to-volume ratio and require relatively high energy to maintain elevated body temperatures (Schmidt-Nielson 1997). Small species such as bats, hummingbirds, rodents, and shrews select shelter (often referred to as roosts) based on microclimate for periods they will be inactive (Calder 1973, Schmidt-Nielson 1997).

A meta-analysis and reviews on forest-roosting bats found that temperate bats used roost trees that were taller, had larger diameters, and in areas of more open canopy and greater snag density than other trees in the forest (Hayes 2003, KalcounisRüppell et al. 2005, Brigham 2007). Large, tall trees that extend high above the canopy may be selected by bats because they are surrounded by few other trees and receive more solar radiation, thus providing warmer thermal regimes (Waldien et al. 2000, Ruczynski 2006). Bats may switch roosts in response to changing microclimates (Kerth et al. 2001, Bartonička and Řehák 2007). Previous research postulates that roost structures that receive increased amounts of solar radiation will facilitate growth and development of juveniles in maternity roosts (Crampton and Barclay 1998, Foster and Kurta 1999).

Although the amount of solar radiation received has been suggested to influence roost selection by forest-roosting bats,

Received: 1 July 2016; Accepted: 23 February 2017

${ }^{1}$ E-mail: kristin.bondo@ucalgary.ca

${ }^{2}$ Present Address: Department of Ecosystem and Public Health, University of Calgary, 3280 Hospital Dr. N.W., Calgary, AB T2N 4Z6, Canada. we are unaware of any studies that have quantified and recorded solar radiation received at roosts over time. Our objectives were to 1) determine whether inexpensive selfbuilt silicon-cell pyranometers, which are used to measure solar irradiance on a planar surface, can be connected to dataloggers and used to measure and record relative solar radiation levels at roost trees used by bats and other wildlife and 2) describe how these devices can be built and calibrated with a commercial pyranometer for a fraction of the cost of commercial versions.

\section{STUDY AREA}

We used pyranometers to measure solar radiation at roost trees used by bats from July to August 2007 and from June to August 2008 in the West Block of Cypress Hills Inter-Provincial Park $\left(49^{\circ} 34^{\prime} \mathrm{N}, 109^{\circ} 53^{\prime} \mathrm{W}\right)$, Saskatchewan, Canada, and on nearby private property. Permission was granted by the park and the landowner to access and climb trees on their property. In Cypress Hills and on the neighboring property, maternity groups of big brown bats (Eptesicus fuscus) roosted in cavities in living and dead trembling aspen (Populus tremuloides) trees infected with heart-rot. They gained access to cavities through entrance holes that were either created naturally or excavated by woodpeckers, including the northern flicker (Colaptes auratus) and red-naped sapsucker (Sphyrapicus nuchalis). Previous research recorded the precise locations of roost trees used by maternity colonies of big brown bats in the area from 1993-2008 (Kalcounis and Brigham 1998, Willis and Brigham 2004, Metheny et al. 2008).

\section{METHODS}

We constructed silicon-cell pyranometers based on educational research pyranometer kits and assembly instructions 
available from the Institute for Earth Science Research and Education (Eagleville, PA, USA). After we designed the first prototype, the University of Regina Machine and Electronics Shops assembled and wired 25 units. We connected pyranometers to a 12-bit temperature datalogger to record data (Onset, Bourne, MA, USA; HOBO U12-006). We calibrated pyranometers under clear sky conditions with a commercially available silicon-cell pyranometer (Apogee Instruments, Inc., Logan, UT, USA; PYR-P). We installed the units onto trees and programmed them to measure solar radiation every $5 \mathrm{~min}$. The approximate cost for the parts to build 25 pyranometers (including spare parts) was US $\$ 200$. The commercial pyranometer cost US $\$ 169$ and dataloggers were US\$90 each. The amount of labor required to assemble and wire a pyranometer was approximately $30 \mathrm{~min}$, but this would be more for someone without basic mechanical or soldering skills. The labor involved to machine the parts in a machine shop using a drill press with Forstner bits, a machine lathe, and an arch punch added approximately $1 \mathrm{hr}$ to build each pyranometer but would be less per unit if the parts were machined in batches.

We deployed 25 pyranometers on 9 potential bat roost trees in the study area from 5 July to 31 August 2007 and 12 pyranometers on 12 potential roost trees from 22 June to 29 August 2008. For 1-6 weeks during 2007, we placed 4 pyranometers on each of 9 trees: 1 as close to the cavity entrance without obstructing the opening, and 1 on the due south, east, and west sides of the tree at approximately the same height as the cavity entrance opening. We did not measure solar radiation on the north side of the tree unless the cavity entrance opening faced that direction because the focus of a concurrent study was to determine how solar radiation at the cavity entrance and on the east, west, and south sides of the tree cavity influenced cavity temperature. During this same time period, we placed pyranometers at different cavities of the same tree in 2 trees. During 2008, we mounted pyranometers on 12 tree roosts on the same day, as close as possible to the cavity entrances without obstructing them, and left them on for approximately 8 weeks. Throughout the duration of the study, we set the commercial pyranometer on a flat level surface with a clear view of the sky to record daily solar radiation. We downloaded data from dataloggers after we removed pyranometers from each tree and downloaded data from the datalogger connected to the commercial pyranometer once a month.

\section{Construction of Pyranometers}

Silicon-cell pyranometers (Fig. 1) were housed inside $50 \times 35 \times 20$-mm plastic acrylonitrile butadiene styrene (ABS) boxes (Hammond Manufacturing, Guelph, ON, Canada; 1551GGY) after we cut a hole in the top to expose the silicon blue photodiode (Luna Optoelectronics, Roanoke, VA, USA; PDB-C139). We inserted the silicon blue photodiode inside 6-mm polyvinyl chloride (PVC) schedule 80 pipe (United States Plastic Corp., Lima, OH, USA; 26320), cut into $2.5-\mathrm{cm}$ long pieces, and covered with a 1-mm thick Teflon ${ }^{\circledR}$ sheet (McMaster-Carr, Elmhurst, IL, USA; 8545 $\mathrm{K} 12)$ cut with an arch punch into disks $1 \mathrm{~cm}$ in diameter. The

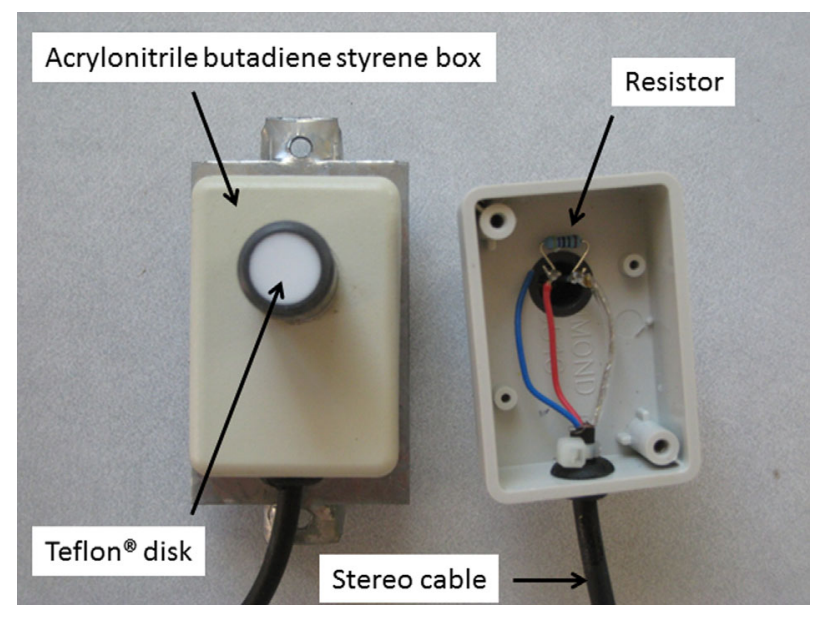

Fig. 1. Front view and interior view of a constructed silicon-cell pyranometer used to measure solar radiation at tree cavity roosts used by big brown bats during summers of 2007 and 2008 in Cypress Hills, Saskatchewan, Canada. The back is removed to show the wiring and components of the circuit.

Teflon ${ }^{\circledR}$ disk was necessary to protect the photodiode-resistor assembly from getting wet and improve the cosine response of the device by diffusing sunlight. We made a circuit by soldering a 499-ohm, 0.25-watt (W) metal film resistor (Yageo, San Jose, CA, USA; MFR-25FBF52-499R) onto the silicon photodiode leads using a $15-25-\mathrm{W}$ soldering iron and $0.79-\mathrm{mm}$ resin-core solder. The purpose of the resistor was to provide a voltage output large enough for the datalogger to record but small enough for it to be linearly proportional to the amount of sunlight falling on the detector.

We drilled a second hole into one side of the ABS box and fitted it with a $0.48-\mathrm{cm}$ rubber grommet through which we threaded a $91.5-\mathrm{cm}$ long, $2.5-\mathrm{mm}$ stereo audio cable after cutting it in half from a $182.9-\mathrm{cm}$ long $2.5-\mathrm{mm}$ male-male stereo cable (PCH Cables, Hillsboro, OR, USA; 201503). We soldered the positive wire and shield of the stereo cable to each of the leads of the silicon photodiode. We inserted the plug of the stereo cable into one channel of the datalogger. One logger could collect data for up to 4 pyranometers.

\section{Pyranometer Calibration}

We calibrated the 25 silicon-cell pyranometers simultaneously face-up on a level surface with a clear view of the sky during a night and a sunny day using the pre-calibrated Apogee silicon-cell pyranometer from 1730 on 12 June to 1605 on 14 June 2007 (Fig. 2). To ensure pyranometers were stationary and in the same plane during calibration, we screwed them onto a leveling plate set on an outdoor table affixed to the ground (Fig. 2). After we leveled the plate, we leveled each pyranometer with a small acrylic bullseye level (McMaster-Carr, Elmhurst, IL, USA; 2147A61).

Dataloggers recorded the output of the pyranometers in volts $(V)$ every $5 \mathrm{~min}$. To determine the amount of shortwave radiation recorded by the Apogee pyranometer, we multiplied the voltage output produced in full sunlight by the calibration constant for the Apogee pyranometer, which was $5,000 \mathrm{~W} / \mathrm{m}^{2}$ per $\mathrm{V}$. We generated calibration constants for 


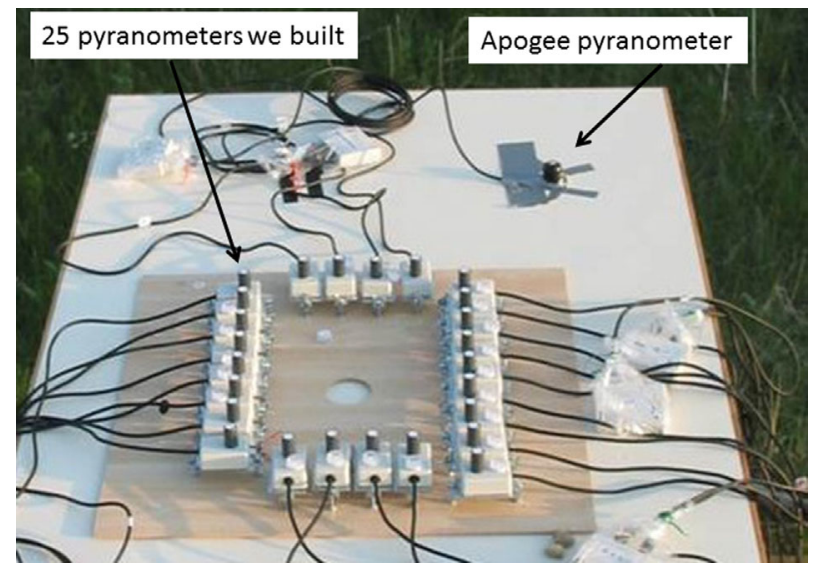

Fig. 2. Calibration of the 25 constructed silicon-cell pyranometers with a commercially available Apogee silicon-cell pyranometer in full view of a clear sky from 1730 on 12 June to 1605 on 14 June 2007 in Cypress Hills, Saskatchewan, Canada.

each individual pyranometer using linear regression in Excel 2010 (Microsoft Corporation, Redmond, WA, USA). The voltage output produced during $5 \mathrm{~min}$ for each pyranometer we built was the dependent variable and the calibrated value in $\mathrm{W} / \mathrm{m}^{2}$ produced per $\mathrm{V}$ for the Apogee pyranometer was the independent variable. We set the $y$-intercept to 0 and recorded the calibration constant for each pyranometer as the slope of the line. For each pyranometer, we multiplied the calibration constant by the instantaneous voltage produced per 5-min interval to yield a value for solar radiation in $\mathrm{W} / \mathrm{m}^{2}$. We calculated calibration constants using all of the voltages produced in 5-min intervals and not just the voltages produced in full sunlight. We converted solar radiation from $\mathrm{W} / \mathrm{m}^{2}$ to kilowatt-hours $/ \mathrm{m}^{2}(\mathrm{kWh}) / \mathrm{m}^{2}$ by multiplying $\mathrm{W} / \mathrm{m}^{2}$ by $12(60 \mathrm{~min} / 5 \mathrm{~min})$ and then dividing by 1,000 .

\section{Deployment and Analysis}

To allow for easy attachment of pyranometers to trees, we drilled 2 holes into a 16 -gauge $3.81 \times 7.62-\mathrm{cm}$ metal nail stop (Simpson-Strong Tie, Brampton, ON, Canada; NS1) and then screwed the plastic ABS boxes onto the plates. To attach the pyranometer to the tree, we inserted one screw through the metal nail stop and then screwed it into the tree (Fig. 3). We wrapped electrical tape around the edges of the ABS box and grommet to make the devices water-resistant. We wrapped the datalogger tightly inside a small plastic bag tied with a twist-tie and put it into a plastic container half filled with cat litter to absorb any moisture. After we installed the pyranometer on the tree, we wiped the Teflon ${ }^{\circledR}$ disk with a Kimwipe (Kimberly-Clark Worldwide, Inc., Roswell, GA, USA; 34120) to remove any debris. When the pyranometers were not deployed, we stored them in plastic bags and containers to protect them from dust, with care taken not to touch the Teflon ${ }^{\circledR}$ disks.

We plotted pyranometer results from 1 August to 5 August 2007 to use as examples because this period included sunny days with clear skies in addition to those with mixed clouds and sun. We plotted these data using STATA (STATA Intercooled 13.1; StataCorp, College Station, TX, USA).

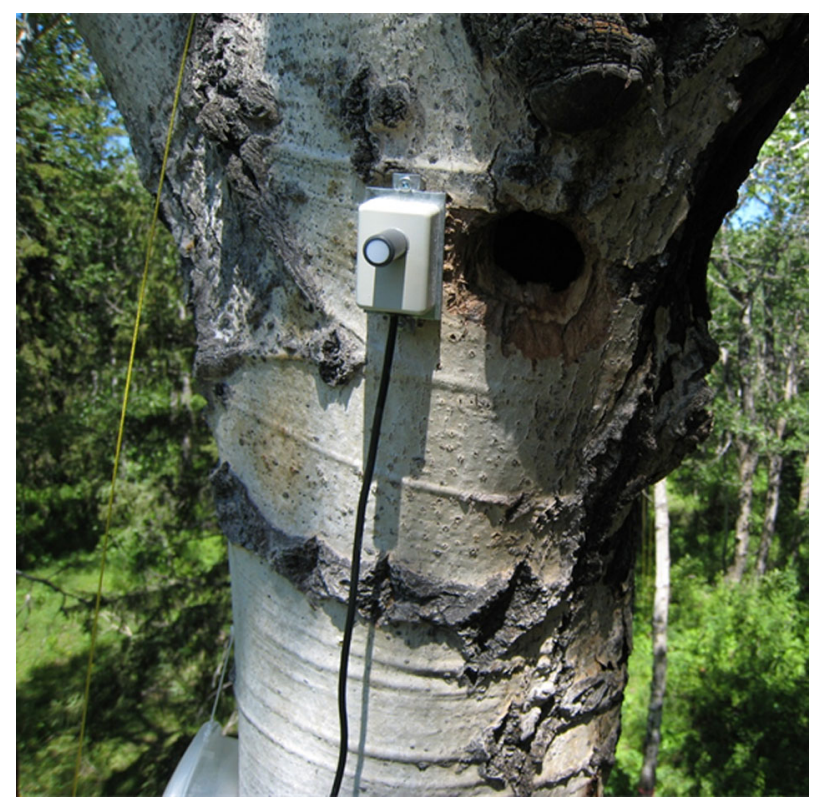

Fig. 3. A pyranometer installed at the cavity entrance of a trembling aspen tree used as a day roost by big brown bats during summers of 2007 and 2008 in Cypress Hills, Saskatchewan, Canada.

\section{RESULTS}

Data from the commercial pyranometer placed horizontally in full view of the sky illustrated peaks that occurred during daylight hours and lack of solar radiation at night (Fig. 4A). The first peak occurred on a clear sunny day with no cloud cover; however, there was some cover on days 3,4 , and 5 , which was depicted in the data by the fluctuations in peak height (Fig. 4A).

The solar radiation results from the commercial pyranometer (Fig. 4B) and calibrated results from all of the pyranometers we constructed were closely comparable (e.g., pyranometers 1-3; Fig. 4C-E). During 2007, calibration constants for each pyranometer ranged from 3,279.8 to $3,759.7(\bar{x} \pm 1 \mathrm{SD}=3,442.5 \pm 110.8)$. After calibration, the mean for all pyranometers every $5 \mathrm{~min}$ was $2.9 \pm 0.06 \mathrm{KWh}$. For each 5-min measurement made during calibration, the mean for all pyranometers ranged from $0.01 \pm 0.00036$ to $13.7 \pm 0.16 \mathrm{KWh}$.

The solar radiation output from the pyranometers mounted on a roost tree used by bats from 1 August to 5 August 2007 showed that the cavity entrance (Fig. 5A), which had an orientation of northeast, received less solar radiation than the south, east, and west sides of the tree cavity (Fig. 5B-D). The cavity entrance and east side of the cavity received the most sunlight in the morning (Fig. 5A and C); the south side of the cavity received the most sunlight during mid-day (Fig. 5B); and the west side of the cavity received the most sunlight during late afternoon (Fig. 5D).

Of the 25 pyranometers and dataloggers that we deployed on roost trees during 2007, only 1 malfunctioned when the Teflon ${ }^{\circledR}$ disk became loose exposing the photodiode. Of the 12 pyranometers deployed in the field during 2008, only 1 malfunctioned because the datalogger cable was chewed by a 

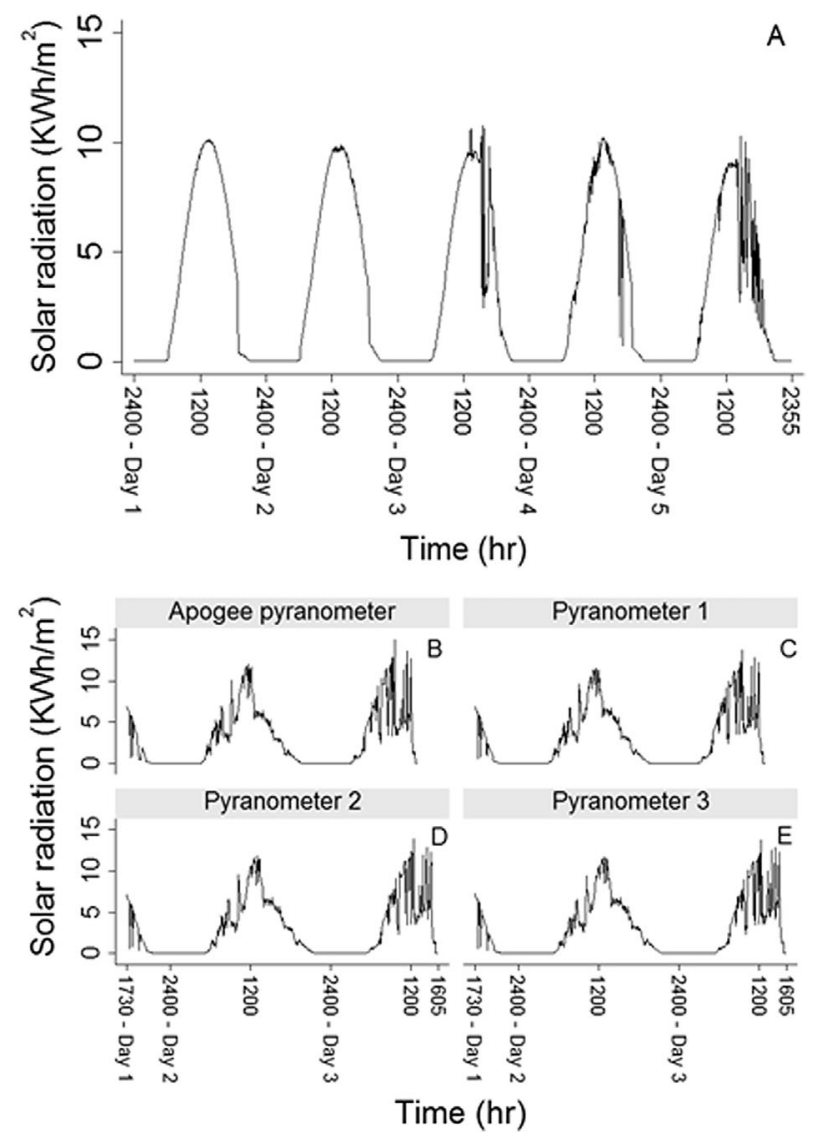

Fig. 4. Output from the commercially available pyranometer placed horizontally in full view of a clear sky from 2400 on 1 August to 2355 on 5 August 2007 in Cypress Hills, Saskatchewan, Canada (A), solar radiation output from the commercial pyranometer (B), and the calibrated results from 3 constructed pyranometers (C-E) placed in full view of a clear sky from 1730 on 12 June to 1605 on 14 June 2007.

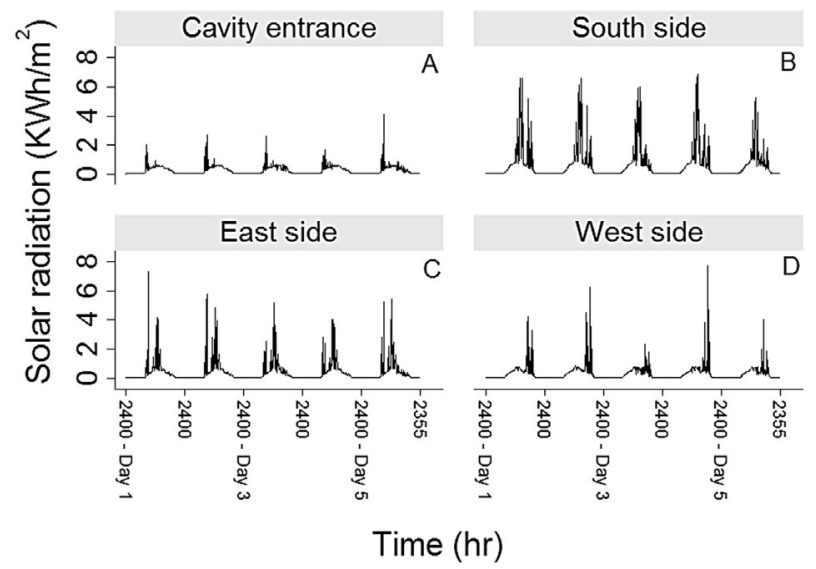

Fig. 5. Solar radiation output of pyranometers mounted from 2400 on 1 August to 2355 on 5 August 2007 at the cavity entrance (A), which had a northeast orientation, and at approximately the same height as the northeast cavity entrance on the due south (B), due east (C), and due west (D) sides of a trembling aspen tree cavity used by big brown bats as a day roost during summers of 2007 and 2008 in Cypress Hills, Saskatchewan, Canada. red squirrel (Tamiasciurus budsonicus) 17 days after it was installed. None of the dataloggers were damaged by rain.

\section{DISCUSSION}

Our results show how silicon-cell pyranometers connected to dataloggers can be used to monitor and record relative levels of solar radiation at used and available roost trees for bats and other wildlife. Although pyranometers are intended to measure total incoming solar radiation (insolation) on a horizontal plane at Earth's surface, they can be mounted in any position for wildlife or ecological applications whose purpose is to quantify relative levels of solar radiation at a site of interest.

The advantage of using silicon-cell pyranometers to measure solar radiation is that they can be built inexpensively and connected to dataloggers, so that relative levels of solar radiation can be quantified and recorded. Another advantage is that the silicon-cell pyranometers we built ourselves were easily made weather-resistant similar to commercially available silicon-cell pyranometers. The HOBO dataloggers that we used in the study have been upgraded (Onset; HOBO datalogger UX120-006M). In addition, the commercial pyranometer has been replaced by a more recent model (Apogee Instruments; SP-110). Retail prices for the upgraded versions of the datalogger and pyranometer are US \$139 and US\$195, respectively.

One limitation of using silicon-cell pyranometers is that they cannot detect radiation from the entire spectrum but sub-sample it. Silicon-cell pyranometers are sensitive to solar radiation in the $300-1,100 \mathrm{~nm}$ band, which represents approximately $70-75 \%$ of the entire terrestrial spectrum (Myers 2011). They are calibrated to estimate the radiation across the entire spectrum in $\mathrm{W} / \mathrm{m}^{2}$. Because of this limitation, some authors have suggested that thermopile pyranometers be used instead, so that light reflected from or transmitted through vegetation will also be detected (Bakken and Kunz 1988). Thermopile pyranometers can cost thousands of dollars, so using them would be impractical in most wildlife studies.

Another limitation of using any kind of pyranometer in the field is that moisture or debris on the diffuser can cause low readings. If material accumulates on the sensor, it can be cleaned using water and a soft cloth or cotton swab (Apogee 2015). The output of all solar radiation sensors tends to decrease over time as they age (Apogee 2016). For continuous outdoor use, the manufacturer of the commercial pyranometer we used recommends sending in the detector for recalibration every 2 years (Apogee 2016). To determine the timing or need for re-calibration, The Clear Sky Calculator or other solar irradiance models can be used to determine shortwave radiation incident on a horizontal surface at any time of the day at any location in the world under cloud-free conditions (Brooks 2013a,b; Apogee 2015).

Future studies deploying pyranometers on trees might consider calibrating them under a variety of conditions in the area and on the surfaces that they will be used in clear and cloudy conditions. Although the pyranometers are relatively small, it is unknown how or if their presence around cavity 
entrances changes use of roost trees by bats or other wildlife. We strongly suspect that bats were not disturbed by continuous placement of pyranometers at their roosts as long as the devices and cables did not block their flight paths. We observed bats using trees with pyranometers placed outside cavities when conducting roost counts for big brown bats during 2007. In a concurrent study, we recorded bats marked with passive-integrated transponders (PIT tags) using a roost that had a pyranometer and a PIT tag reader antenna at the cavity entrance.

Using pyranometers in the field would allow for testing the hypothesis that bats select roosts based on relative amounts of solar radiation received. Pyranometers may also be used to quantify relative levels of solar radiation at potential bat roosting sites and aid in making decisions on where to place bat houses.

\section{ACKNOWLEDGMENTS}

E. Gillam, J. Kilgour, and A. Migaj provided valuable assistance in the field. Arboriculture Canada Training and Education provided expert tree climbing equipment and training. D. Kolybaba and K. Wolbaum from the University of Regina helped us build and wire the pyranometers based on a prototype model, which $\mathrm{P}$. Bondo assisted in constructing. The Associate Editor and 2 anonymous reviewers provided helpful comments in revising and editing the manuscript. This work was funded through a grant by the Natural Science and Engineering Research Council of Canada (NSERC) to RMB and by scholarships provided by Nature Regina, the American Society of Mammalogists, and the University of Regina, Faculty of Graduate Studies and Research to KJB.

\section{LITERATURE CITED}

Apogee. 2015. Apogee instruments owner's manual pyranometer. SP-110 and SP-230. http://www.apogeeinstruments.com/content/SP-110-manual.pdf. Accessed 20 Apr 2016.

Apogee. 2016. Apogee pyranometer technical information. http://www. apogeeinstruments.com/apogee-pyranometer-technical-information/. Accessed 2 May 2016.

Bakken, G. S., and T. H. Kunz. 1988. Microclimate methods. Pages 303-332 in T. H. Kunz, editor. Ecological and behavioral methods for the study of bats. Smithsonian Institution Press, Washington, D.C., USA.
Bartonička, T., and Z. Řehák. 2007. Influence of the microclimate of bat boxes on their occupation by the soprano pipistrelle Pipistrellus pygmaeus: possible cause of roost switching. Acta Chiropterologica 9:517-526.

Brigham, R. M. 2007. Forest-living bats: what we know and what we need to learn. Pages 1-15 in M. J. Lacki, J. P. Hayes, and A. Kurta, editors. Bats in forests: conservation and management. John Hopkins University Press, Baltimore, Maryland, USA.

Brooks, D. R. 2013a. Bird and Hulstrom's solar irradiance model. http:// www.instesre.org/Solar/BirdModelNew.htm. Accessed 25 Jun 2016.

Brooks, D. R. 2013b. A simple insolation model. http://www.instesre.org/ Solar/insolation.htm. Accessed 25 Jun 2016.

Calder, W. A. 1973. Microclimate selection during nesting of hummingbirds in the Rocky Mountains. Ecology 54:127-134.

Crampton, L. H., and R. M. R. Barclay. 1998. Selection of roosting and foraging habitat by bats in different-aged aspen mixedwood stands. Conservation Biology 12:1347-1358.

Foster, R. W., and A. Kurta. 1999. Roosting ecology of the northern bat (Myotis septentrionalis) and comparisons with the Indiana bat (Myotis sodalis). Journal of Mammalogy 80:659-672.

Hayes, J. P. 2003. Habitat ecology and conservation of bats in western coniferous forests. Pages 81-119 in C. J. Zabel, and R. G. Anthony, editors. Mammal community dynamics in coniferous forests of western North America: management and conservation. Cambridge University Press, Cambridge, United Kingdom.

Kalcounis, M. C., and R. M. Brigham. 1998. Secondary use of aspen cavities by tree-roosting big brown bats. Journal of Wildlife Management 62:603-611.

Kalcounis-Rüppell, M. C., J. M. Psyllakis, and R. M. Brigham. 2005. Tree roost selection by bats: an empirical synthesis using meta-analysis. Wildlife Society Bulletin 33:1123-1132.

Kerth, G., K. Weissmann, and B. König. 2001. Day roost selection in female Bechstein's bats (Myotis bechsteinii): a field experiment to determine the influence of roost temperature. Oecologia 126:1-9.

Metheny, J. D., M. C., Kalcounis-Rueppell, K. J. Bondo, and R. M. Brigham. 2008. A genetic analysis of group movement in an isolated population of tree-roosting bats. Proceedings of the Royal Society of London B: Biological Sciences 275:2265-2272.

Myers, D. R. 2011. Quantitative analysis of spectral impacts on silicon photodiode radiometers. Pages 17-20 in American Solar Energy Society Solar Conference Proceedings, 17-21 May, Raleigh, North Carolina, USA.

Ruczynski, I. 2006. Influence of temperature on maternity roost selection by noctule bats (Nyctalus noctula) and Leisler's bats ( $N$. leisleri) in Bialowieza Primeval Forest, Poland. Canadian Journal of Zoology 84:900-907.

Schmidt-Nielson, K. 1997. Animal physiology. Fifth edition. Cambridge University Press, Cambridge, United Kingdom.

Waldien, D. L., J. P. Hayes, and E. B. Arnett. 2000. Day roosts of female long-eared myotis in western Oregon. Journal of Wildlife Management 61:674-684

Willis, C. K. R., and R. M. Brigham. 2004. Roost switching, roost sharing and social cohesion: forest-dwelling big brown bats, Eptesicus fuscus, conform to the fission-fusion model. Animal Behaviour 68:495-505.

Associate Editor: Ober. 